\title{
ESTIMATION OF BIOMASS AND CARBON CONTENT IN EX-COAL MINE LANDS
}

\author{
Wirawan Noor Hadi ${ }^{1}$, Gusti Muhammad Hatta², Yudi Firmanul Arifin², Fakhrur Razie ${ }^{3}$ \\ ${ }^{1}$ Graduate student, Forestry Faculty, Lambung Mangkurat University \\ ${ }^{2}$ Lecturer, Silviculture Department, Forestry Faculty, Lambung Mangkurat University \\ ${ }^{3}$ Lecturer, Soil Sciences, Agricultural Faculty, Lambung Mangkurat University \\ Banjarbaru, South Kalimantan, Indonesia
}

\section{Email: wirawan_hadi@banpuindo.co.id}

\begin{abstract}
Potentially acid forming (PAF) and non-acid forming (NAF) lands are two types of lands found in ex-coal mine lands. These lands are similar to wetlands that have the potential to produce acid. PT. Jorong Barutama Greston is one of the coal mining companies required by the government to carry out reclamation by revegetation activities. Revegetation of excoal mine lands has generated plant biomass and carbon content to a specific value. The purposes of this study were to compare the amount of biomass and carbon content in excoal mine lands and to determine the best treatment for the ex-coal mine lands. The methods began with creating the measuring plots on the lands with different soil color (gray and brown). The soil color difference was determined by laboratory analysis test. For each different soil, the land revegetation was implemented with different treatments, 4 ameliorant treatments and 2 fertilization treatments so there were 8 units of treatments. Biomass and carbon content in each treatment unit were calculated by taking 4 plants as the laboratory test samples. The carbon content was calculated using the formula calculating the carbon of undergrowth with a diameter of $<5 \mathrm{~cm}$. The results showed that the biomass and carbon content of plants in plot II were 17 times higher than those in plot I. The best treatment in plot I was the use of lime, bokashi and LOF (Liquid Organic Fertilizer) while the best treatment in plot II was the use of bokashi.
\end{abstract}

Keywords: Biomass, Carbon, Land, Revegetation

\section{INTRODUCTION}

Wetlands are lands that are always inundated with water either permanently or seasonally. The stagnant water has high water content. Various ecosystems in wetlands include forests, rivers, swamps, lakes, rivers, mangroves, peat forests, floodplains, coasts, fields, and coral reefs.

The functions of wetlands have changed, from forests to industrial activities including mining, plantation, agriculture and even housing. In coal mining industries, wetlands that were previously forests have changed into ponds and earth mounds that generate overburden that could potentially inhibit plant growth. According to Alimano (2011), the overburden consists of two, namely Potentially Acid Forming (PAF) overburden and Non-Acid Forming (NAF) overburden. The overburden with the $\mathrm{pH}$ content of $<4.5$ is the type of overburden in NAF category, and the pH content of $\geq 4.5$ is in PAF category.

Megawati et al. (2011) states that the condition of acid soil can hinder plant growth on the land formerly used for coal mine. This is due to the high content of $\mathrm{Al}$ to be toxic to plants. Firmansyah (2011) states that there are several ways to manage and improve the acidic land and Al toxicity, such as the provision of lime, phosphate rock, and organic matter, as well as the saturation with heavy $\mathrm{P}$ fertilization.

The inhibition of plant growth will also inhibit the production of biomass and carbon content of plants. Carbon content of plants is produced by plant parts such as roots, stems and leaves. These parts of plant contain high carbon content.

PT. Jorong Barutama Greston is a mining company that has been carrying out reclamation until now. The reclamation activities in the revegetation program encounter some obstacles, especially the acid land condition. The success of the program in the area of PT. JBG is still low with the average percentage of growth and health of the plants below $80 \%$, namely $59.38 \%$ and $50.01 \%$, respectively (Setiadi, 2015).

The purposes of this study were to compare the amount of biomass and carbon 
content of ex-coal mine lands, and to determine the best treatment for the ex-coal mine lands. The results of this study are expected to provide the basis for the calculation and improvement of the biomass and carbon content in wetlands to reduce the greenhouse gas emissions to global warming.

\section{MATERIALS AND METHODS}

This study was conducted for 4 months from January to May 2016. The study began with the creation of study plots with a size of $252 \mathrm{~m}^{2}$. The number of existing plants in the plots was 80 plants with 4 ameliorant treatments and 2 fertilization treatments. The materials used in the ameliorant treatments were lime and organic matters, and in the fertilization treatment (without fertilizer and with fertilizer) was Liquid Organic Fertilizer (LOF).

The plots were made at 2 locations. The locations were chosen by observing the color of the soil. There were 2 soil colors observed, brown and gray. In each location was then established a measuring plot. The soil sampling in each measuring plot was carried out by taking composite. Composite was the soil mixture representing the measuring plot. Soil samples were taken from 5 sampling points and were then composited into one.

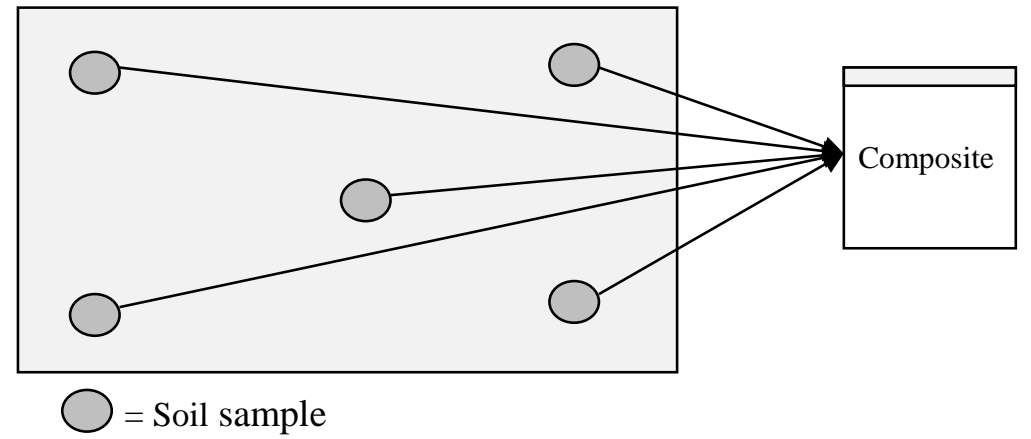

Figure 1 Composite technique of soil samples

The plant species planted was Acacium mangium with the size of $30-50 \mathrm{~cm}$. The treatments given were 4 ameliorant and 2 fertilization treatments, so there were 8 treatment units. Each treatment had 10 replication units. From each repetition, four replications were taken for the test of biomass weight and the calculation of carbon content using the method of undergrowth calculation. According to Hairiah et al. (2011), the calculation of undergrowth with a diameter of $<5 \mathrm{~cm}$ as follows:

$\sum$ DW $=\frac{\text { Sample of Dry Weight }(\mathrm{g})}{\text { Sample of Wet Weight }(\mathrm{g})} \times$ Total WW (g)

$\mathrm{DW}=$ Dry Weight and $\mathrm{WW}=$ Wet Weight

\section{Carbon Calculation:}

Carbon Content $=$ Dry Weight of Biomassa (g/treatment unit) $\times 0.46$

The estimation of biomass and calculation of carbon content were performed after 4 months. The number of plants taken from each treatment was four. The stem of each plant was cut with a height of $10 \mathrm{~cm}$ from the ground, and then cut into pieces to be packed in a large envelope. The pieces that had been packed were delivered to the soil science laboratory of Agricultural Faculty, Lambung Mangkurat University, Banjarbaru, for the measurement of biomass weight.

The data analysis was performed descriptively based on the results from the soil laboratory test, plant biomass and carbon content calculation. The analyses were associated with the relationship between the soil $\mathrm{pH}$, various nutrient contents, plant biomass, and carbon content. The results of laboratory analyses were then converted into the unit of tons/ha/year.

\section{RESULTS AND DISCUSSION}

The results were based on the two different lands. The lands were divided into 2 plots, plot I and II. Based on the laboratory test results, the analysis of the soil in plot I showed that the content of soil $\mathrm{pH}$ was very acidic. The content of very acidic soil $\mathrm{pH}$ showed low nutrient content. There was also a high value of $\mathrm{Al}$ (5.93 me/100g soil). In plot II, the content 
of soil pH was categorized acidic ( $\mathrm{pH}$ of 4.92), indicating nutrient content ranging from very low to low. However, there was no Al element that was toxic in plot II because the Al content in this plot was only $2.44 \mathrm{me} / 100 \mathrm{~g}$ soil. Setiadi (2012) states that when $\mathrm{Al}$ is more than 3 me $/ 100 \mathrm{~g}$ soil, it can impede the growth of plants, dwarf the plants, cause drought, and kill the plants.

From each plot, four plant samples were taken to be tested for biomass and carbon content. The plant biomass in plot I was the highest ( 0.23 tons/ha/year) and the carbon content in this plot was 0.11 tons/ha/year that was found in the treatments of lime, bokashi, and liquid organic fertilizer (LOF). Lime can increase the soil pH (Yenni, 2012). Bokashi is an organic material which can improve soil physical and chemical properties that can support plant growth (Nismawati, et al., 2013). Meanwhile in plot II, the highest value of biomass was in the treatment of bokashi (3.93 tons/ha/year), and the carbon content was 1.81 tons/ha/year. Bokashi is an organic matter that provides nutrients for plants and good growing space for the soil because it provides spaces for the pores of the newly formed roots around the root area to easily penetrate the soil.

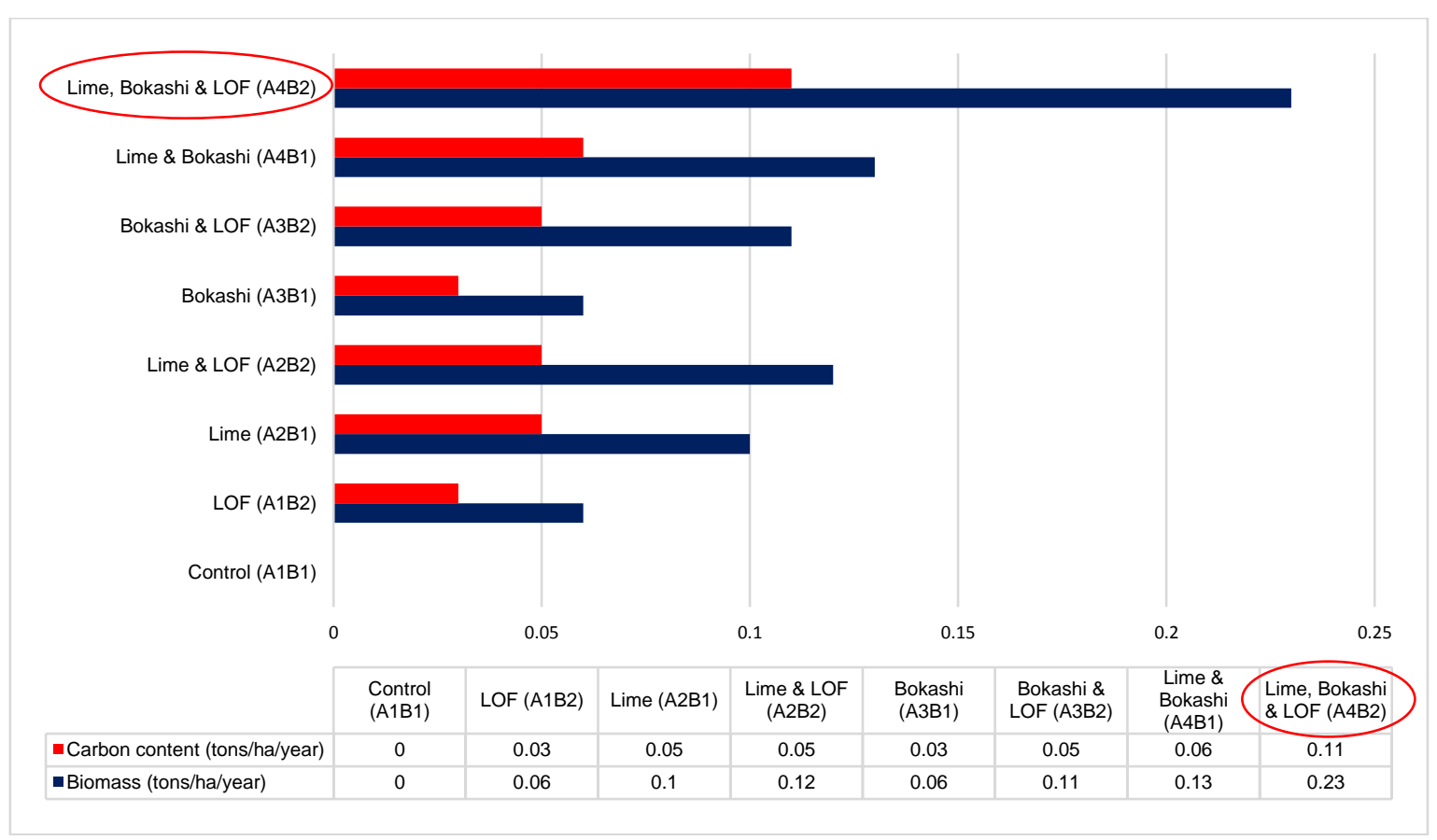

Figure 2 Biomass and carbon content at all treatments in plot I

It can be seen from data in Figure 2 that there were no values of biomass and carbon content in plot I, which was the control or without treatment. This was due to the high mortality rate of up to $90 \%$. The death was caused by the high content of Al that was toxic and the micro pores of the soil which made the soil porous.

Each treatment in plot I showed that the biomass value grew high because of the addition of liquid organic fertilizer (LOF) in each treatment. Without the LOF, plants can produce biomass but the amount of the biomass was less than those with LOF. The LOF adds nutrients in plants.

Based on the minimum law of Liebeg, the limiting factor is the supporting material in a minimum number of living organisms (Rohmani, 2013). In plot I, the limiting factor which is the minimum material was nutrient $\mathrm{K}$. When the use of lime was able to precipitate $\mathrm{Al}$, the nutrients became available to plants, but the value of biomass production was still low because there was nutrient $\mathrm{K}$ that was the limiting factor in the plant growth.

The addition of Bokashi increased the production of plant biomass because bokashi gave the effect of adding nutrient $\mathrm{K}$ to plants. When the use of lime could raise the $\mathrm{pH}$ and reduce the toxic effect of $\mathrm{Al}$, Bokashi was able to improve nutrient $\mathrm{K}$ as the limiting factor. When LOF was added, the production of biomass in plot I showed the maximum result. It can be therefore concluded from this 
analysis that the use of lime, Bokashi and LOF was the best treatment to improve the biomass production and carbon content of plants.

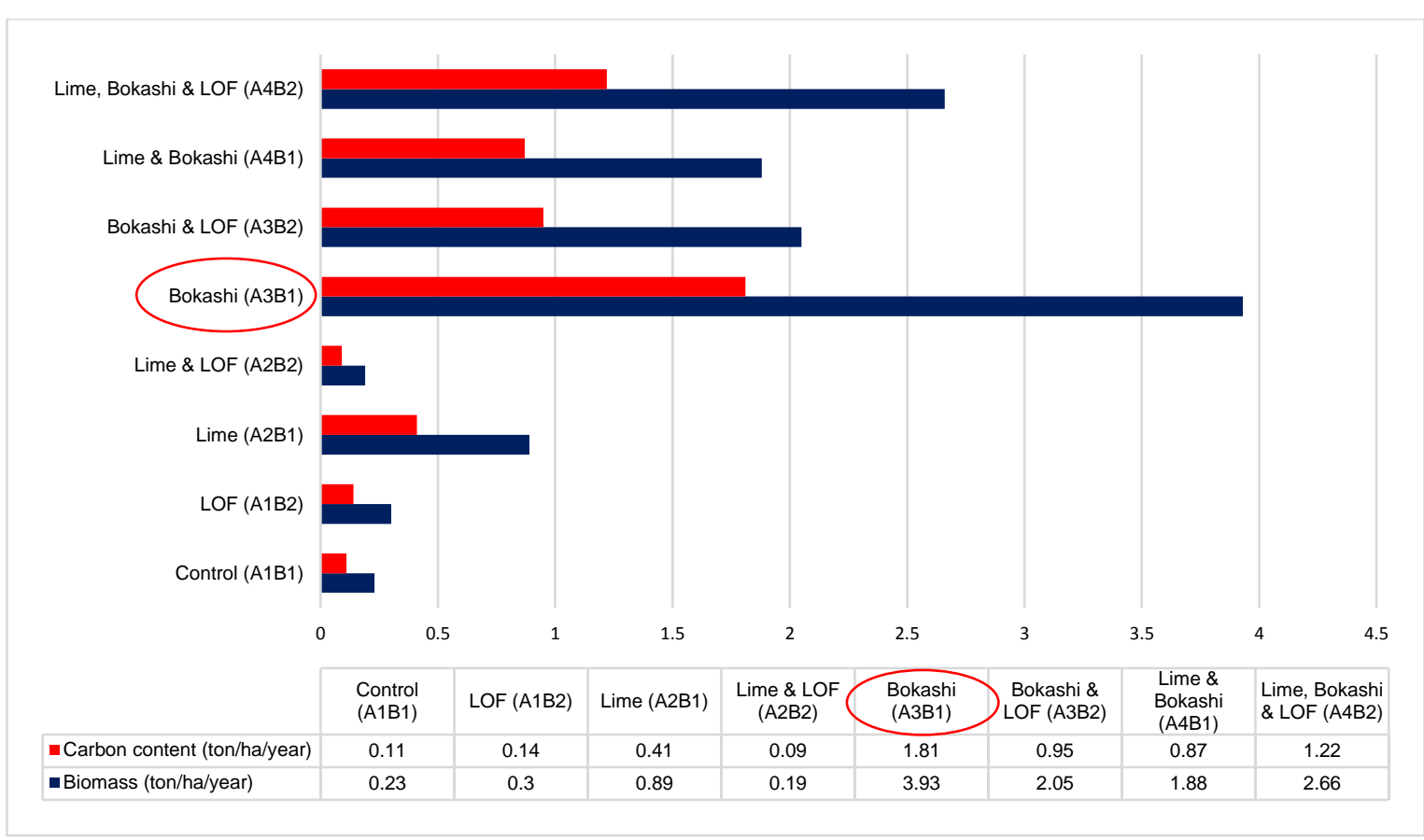

Figure 3 Production of biomass and carbon content of plants in plot II

The acidic land with the $\mathrm{pH}$ content of 4.92 was the land in plot II. This land had a nutrient value from very low to low, but there was no trace of Al content up to toxic level. In addition, the porous soil in plot II was due to the texture of the soil which was sandy clay loam.

The production of biomass and carbon content in each treatment in plot II varied from one another. The provision of Bokashi at each planting hole gave the best effect in producing the biomass (3.93 tons/ha/year) and carbon content (1.81 tons/ha/year). The value of biomass in Bokashi treatment was higher than that in other treatments (Figure 3 ). The use of lime was not needed in plot II because there was no toxic Al element. The content of Al was still below $3 \mathrm{me} / 100 \mathrm{~g}$ soil.

The physical property of soil that supported the growth of plants in plot II was the texture of soil that was sandy clay loam. This soil texture provided the room for the plant roots to easily penetrate (infiltrate) into the ground. This also gave the room to the plants for the maximum nutrient uptake mechanism. After revegetation activities, the nutrient solution approached the plant roots. The process of nutrient approaching the rooting area was called the nutrient uptake mechanism through mass flow. When the plant roots absorbed nutrients through mass flow, the exchange of nutrients would take place. The cations ( $\mathrm{N}, \mathrm{P}, \mathrm{K}, \mathrm{Ca}, \mathrm{Mg}$ ) were absorbed by plants and $\mathrm{H}^{+}$ions moved out of the plant. The anions $\left(\mathrm{H}^{2} \mathrm{PO}^{-4}, \mathrm{NO}^{3-}, \mathrm{SO}_{4}^{-2}\right)$ absorbed by plants were interchanged with the release of $\mathrm{HCO}_{3}$ - in plants (Madjid 2007). As a result of the advantage of biomass production, the biomass in plot II was 17 times higher than the biomass in plot I.

\section{CONCLUSION AND SUGGESTION}

The biomass and carbon content of plants in plot II was 17 times higher than those in plot I. The best treatments in plot I were the use of lime, bokashi and liquid organic fertilizer while in plot II the use of bokashi. It is suggested to improve the soil in highly acidic overburden dump with organic fertilizers or the use of plant species tolerant to acidic $\mathrm{pH}$, such as gelam and eucalyptus.

\section{REFERENCES}

Alimano, M. (2011). Draft Guidelines of Overburden Dump Management in 
Indonesia Mineral Mines. Centre for Research and Development of Mineral and Coal Technology. Bandung.

Firmansyah, M.A. (2010). Plant Response to Aluminum. Agipura. 6 (2): 807-818.

Hairiah, K. Ekadinata, A, Sari, RR., and Rahayu, S. (2011). Measurement of Carbon Storage: From Land Level to Landscape. Practical Guidelines. Second Edition. Bogor. World Agroforestry Centre, ICRAF SEA Regional Office, University of Brawijaya (UB), Malang, Indonesia $\mathrm{xxp}$.

Madjid, A. (2007). Nutrient Intake Mechanism. Retrieved September 20, 2016 from http://dasar2ilmutanah.

blogspot.co.id/2007/11/mekanismepenyerapan-hara.html.

Megawati, N., Wasis, B., and Setiadi, Y. (2014). Growth Response of Acacia mangium Wild to Addition of Lime and HSC (Humic Substance Complex) in Ex-coal Mine Land. Thesis. Bogor Agricultural University.

Nismawati, Wulandari, R., and Irmasari (2013). Effects of Various Doses of Bokashi on the Sapling Growth of Kemiri (Aleurites moluccana L. Willd.). Warta Rimba 1(1).

Soil Research Center (1983). Assessment Criteria of Soil Chemical Properties. Bogor: Center for Agricultural Research and Development, Department of Agriculture.

Rohmadi, M.Y. (2013). Limiting Factors. Limiting Factors 1(1):1-6.

Setiadi, Y. (2012). Soil Amendment of Post Mined Land. Unpublished. Forestry Faculty. Bogor Agricultural University.

Setiadi, A. (2015). Evaluation of the success of Plants for Revegetation of Post Coil mined Lands at Blok M1W, PT. Jorong Barutama Greston, South Kalimantan. Thesis. Bogor Agricultural University. 